\title{
Radon exhalation rates from zircon sands and ceramic tiles in Italy
}

\author{
S. Verità ${ }^{1,2}$, S. Righi ${ }^{1,2}$, R. Guerra ${ }^{1,2}$ and M. Jeyapandian ${ }^{1,3}$ \\ ${ }^{1}$ Centro Interdipartimentale di Ricerca per le Scienze Ambientali (C.I.R.S.A.), \\ University of Bologna, via S. Alberto 163, 48100 Ravenna, Italy \\ ${ }^{2}$ Department of Physics, University of Bologna, Viale B. Pichat 6/2, 40127 Bologna, Italy \\ ${ }^{3}$ Solid State and Radiation Physics Lab., Department of Physics, Bharathiar University, \\ 641046 Coimbatore, India
}

\begin{abstract}
Naturally occurring radionuclides in building materials are sources of external and internal exposure in dwellings. External radiation exposure is caused by the gamma radiation originating from members of uranium and thorium decay chain and from ${ }^{40} \mathrm{~K}$. Internal radiation exposure, mainly affecting the respiratory tract, is due to the short-lived daughter products of radon which are exhaled from building materials into room air. The objective of this study is to measure the radon exhalation rates from zircon materials, flours and sands, used as raw materials in the porous fired tiles body and from the final products (porcelain tiles usually commercialized in Italy). The radon exhalation rates for the zircon flours and sands ranged from 0.17 to $1.9 \mathrm{~Bq} \mathrm{~kg}^{-1} \mathrm{~h}^{-1}$, and from 0.090 to $0.20 \mathrm{~Bq} \mathrm{~kg}^{-1} \mathrm{~h}^{-1} ;{ }^{222} \mathrm{Rn}$ exhalation rates for most of the porcelain stoneware tiles are near or below the minimum detectable limit (LLD) of $0.0004 \mathrm{~Bq} \mathrm{~kg}^{-1} \mathrm{~h}^{-1}$.
\end{abstract}

\section{INTRODUCTION}

Zircon (zirconium silicate, $\mathrm{ZrSiO} 4$ ) is a mineral that occurs in small quantities in a wide range of igneous, sedimentary, and metamorphic rocks. High purity zircon can be found in deposits close to the American, Australian and South African coasts. Zircon is also a by-product of the mining and processing of heavy-minerals sands for titanium (ilmenite, rutile) or tin minerals. One of the most important use of zircon is within the ceramic industry for the production of ceramic tiles and sanitary ware. The use of micronized zircon and zircon flour in ceramic products accounts for almost half of the worldwide consumption of zircon (Table 1). Zircon is characterized by several properties that are important for ceramic applications, including high strength, high fracture toughness, excellent wear resistance, high hardness, excellent chemical resistance, and very good refractory properties.

In porous fired tiles and sanitary ware, ceramic has a two-piece body made up of a clay-based ceramic body covered with a glaze to provide waterproofing, durability and decoration. Zircon, in the form of sand and/or flour, is added to the glaze as opacifier and whitening agent (15-20\%). In contrast, porcelain stoneware tiles have a one-piece ceramic body composed of clays, quartz, feldspars together with zircon (1-10\%). The surface of these tiles may be glazed or unglazed. All zircon materials contain uranium and thorium in the crystal lattice. As a result of the high chemical inertness of zircon, most of the uranium and thorium found is that which was present during the crystallization of the mineral from the molten host rock (although some may also occur within other minerals present as inclusions in the zircon sand grains, for example monazite). The uranium and thorium atoms and their decay products are bound within the zircon crystal structure, substituting for a small number of zirconium atoms. In most other uranium-containing minerals, including uranium ores, the uranium atoms are not bound within the crystalline matrix but form part of the cementing material between the grains. The nature of the zircon crystal is such that the removal of uranium and thorium is not easily accomplished without destruction of the crystal lattice. 
Basically two radiation exposure pathways are associated with ceramic tiles and other building materials: external exposure due to gamma-decay of naturally-occurring radionuclides, and internal exposure through inhalation of radon gas and its short-lived decay products. This study reports activity concentrations of ${ }^{226} \mathrm{Ra},{ }^{232} \mathrm{Th}$ and ${ }^{40} \mathrm{~K}$, radon exhalation rates and radon emanation coefficient from zircon materials, such as zircon sands and zircon flours, and Italian commercial porcelain stoneware tiles.

Table 1. Relative zircon consumption by region [1].

\begin{tabular}{|l|c|}
\hline & Relative consumption (\%) \\
\hline Europe & 36 \\
\hline China & 20 \\
\hline North America & 14 \\
\hline Asia-Pacific & 14 \\
\hline Japan & 7 \\
\hline Rest of the world & 9 \\
\hline
\end{tabular}

\section{MATERIALS AND METHODS}

\subsection{Sampling procedure}

The most commonly raw materials of concern used in the Italian ceramic industry (zircon flours and sands), and different types of porcelain stoneware tiles were analyzed for naturally-occurring radionuclides and radon exhalation rates. Material types and grain-size characteristics are listed in Table 2. In order to determine the radon specific exhalation rate, an amount of about $50 \mathrm{~g}$ of zircon flour, and about $100 \mathrm{~g}$ of zircon sand was used for each measurement. For the same purpose, tile samples have been cut into smaller pieces with an average dimension of about $5 \times 5 \mathrm{~cm}$, and a mass of $30-60 \mathrm{~g}$.

Table 2. Types of zircon material and porcelain tiles analysed. Grain-size measurements are reported for zircon sands and flours.

\begin{tabular}{|l|c|c|c|c|c|c|c|c|}
\hline Code & Sample & $\begin{array}{c}\text { Grain size } \\
(\boldsymbol{\mu} \mathbf{m})\end{array}$ & Code & Sample & $\begin{array}{c}\text { Grain size } \\
(\boldsymbol{\mu m})\end{array}$ & Code & Sample & $\begin{array}{c}\text { Original size } \\
(\mathbf{c m})\end{array}$ \\
\hline 01 & Zircon flour & $2.30 \pm 1.60$ & 15 & Zircon flour & $2.90 \pm 2.60$ & 28 & Grey porcelain tile & $33 \times 33$ \\
\hline 02 & Zircon flour & $2.60 \pm 2.20$ & 16 & Zircon flour & $12.30 \pm 9.00$ & 29 & Porcelain tile & $45.2 \times 45.2$ \\
\hline 03 & Zircon flour & $2.10 \pm 1.40$ & 17 & Zircon flour & - & 30 & White porcelain tile & $30 \times 40$ \\
\hline 04 & Zircon flour & $2.30 \pm 1.60$ & 18 & Zircon flour & $12.00 \pm 9.50$ & 31 & Porcelain tile & $45 \times 45$ \\
\hline 05 & Zircon flour & $2.40 \pm 1.90$ & 19 & Zircon flour & - & 32 & Porcelain tile & $34 \times 34$ \\
\hline 06 & Zircon flour & $2.30 \pm 1.60$ & 20 & Zircon flour & - & 33 & Porcelain tile & $30 \times 30$ \\
\hline 07 & Zircon flour & $5.70 \pm 4.00$ & 21 & Zircon flour & - & 34 & White porcelain tile & $32.5 \times 32.5$ \\
\hline 08 & Zircon flour & $2.70 \pm 2.10$ & 22 & Zircon sand & $90 \pm 50$ & 35 & Porcelain tile & $45 \times 45$ \\
\hline 09 & Zircon flour & $3.60 \pm 3.00$ & 23 & Zircon sand & $90 \pm 40$ & 36 & Porcelain tile & $60 \times 15$ \\
\hline 10 & Zircon flour & $2.30 \pm 1.60$ & 24 & Zircon sand & $90 \pm 30$ & 37 & Porcelain tile & $30 \times 30$ \\
\hline 11 & Zircon flour & $2.20 \pm 1.50$ & 25 & Zircon sand & $90 \pm 40$ & 38 & Porcelain tile & $11.5 \times 11.5$ \\
\hline 12 & Zircon flour & $2.40 \pm 1.90$ & 26 & Zircon sand & $90 \pm 30$ & 39 & Porcelain tile & $30 \times 60$ \\
\hline 13 & Zircon flour & $2.80 \pm 2.10$ & 27 & Zircon sand & $90 \pm 40$ & & & \\
\hline 14 & Zircon flour & $2.90 \pm 2.60$ & & & & & & \\
\hline
\end{tabular}

\subsection{Gamma-ray spectrometry measurements}

Natural activity concentrations were measured by high-resolution $\gamma$-ray spectroscopy. The system consists of a coaxial high purity germanium detector of $22.6 \%$ nominal relative efficiency, and a resolution of $1.9 \mathrm{keV}$ at $1.33 \mathrm{MeV}\left({ }^{60} \mathrm{Co}\right)$. The detector was calibrated using a mixed radionuclide 
solution, containing ${ }^{241} \mathrm{Am},{ }^{109} \mathrm{Cd},{ }^{57} \mathrm{Co},{ }^{139} \mathrm{Ce},{ }^{60} \mathrm{Co},{ }^{113} \mathrm{Sn},{ }^{85} \mathrm{Sr},{ }^{137} \mathrm{Cs}$ and ${ }^{88} \mathrm{Y}$, certified by the Commissariat à l'Energie Atomique (CEA), covering an energy range of approximately 60-1800 keV. Quality assurance of the measurements were assessed through the analysis of Standard Reference Material IAEA soil-375.

Samples were dried, homogenized, packed, sealed in $450 \mathrm{~mL}$ Marinelli beakers, and kept for about three weeks before measurement, in order to achieve radioactive equilibrium between ${ }^{226} \mathrm{Ra},{ }^{222} \mathrm{Rn}$ and its short-lived decay products. Short-lived daughters with more easily measured gamma-ray emissions such as ${ }^{214} \mathrm{~Pb},{ }^{214} \mathrm{Bi},{ }^{228} \mathrm{Ac}$ and ${ }^{212} \mathrm{~Pb}$ were used for proxy determinations of the activity concentrations of their respective parents ${ }^{226} \mathrm{Ra}$ and ${ }^{232} \mathrm{Th}$. Gamma-ray peaks of 609.32 and $1120.28 \mathrm{keV}\left({ }^{214} \mathrm{Bi}\right)$, 295.21 and $351.92 \mathrm{keV}\left({ }^{214} \mathrm{~Pb}\right), 338.40,911.07$ and $968.90 \mathrm{keV}\left({ }^{228} \mathrm{Ac}\right)$, and $238.63 \mathrm{keV}\left({ }^{212} \mathrm{~Pb}\right)$, and $1460,83 \mathrm{keV}\left({ }^{40} \mathrm{~K}\right)$ were used.

Spectrum analysis was performed using a Gamma 2000 Silena v. 2.0 software. All sample were counted for $60,000 \mathrm{~s}$, and measuring times were sufficient to ensure that the overall uncertainty was generally lower than $10 \%$ at a $95 \%$ confidence interval. The background was subtracted from each spectrum.

\subsection{Measuring the rate of radon exhalation from zircon sands, zircon flours and ceramic tiles}

The radon exhalation rate was measured with the standard commercially available E-Perm system, which consisted in a E-PERM $®$ electret ion chamber measuring the ${ }^{222} \mathrm{Rn}$ activity concentration accumulated in a glass jar. The E-Perm procedure has been extensively described by Kotrappa et al. $[2,3]$. Briefly, measurements consisted in sealing the sample with one of these monitors within an exposure container, and determining the average equilibrium of ${ }^{222} \mathrm{Rn}$ gas concentration during the exposure time period. The accumulation time was set at 20 days for ceramic tiles, 10 days for zircon sands, and 3 days for zircon flours (Figure 1). Triplicate measurements were carried out for each sample to take into account the natural variability of radon emanation. Equation (1) gives the ${ }^{222} \mathrm{Rn}$ activity concentration growth, $C_{R n}\left(\mathrm{~Bq} / \mathrm{m}^{3}\right)$ :

$$
C_{R n}=\frac{E\left(1-e^{-\lambda_{R n} t}\right)}{V \lambda_{R n} m}+C_{R n}^{0} e^{-\lambda_{R n} t}
$$

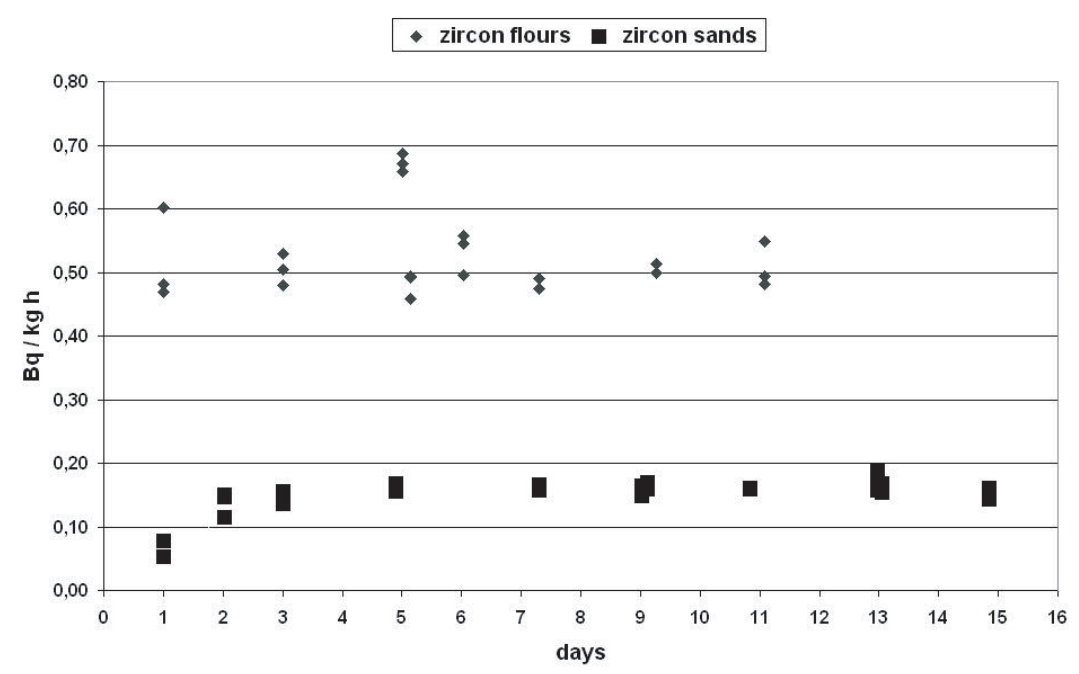

Figure 1. Accumulation time for zircon sands and zircon flours. 
where $E$ is the specific exhalation rate $\left(\mathrm{Bq} \mathrm{kg}^{-1} \mathrm{~h}^{-1}\right)$ from the sample, $\lambda_{R n}$ is the ${ }^{222} \mathrm{Rn}$ decay constant $\left(\mathrm{h}^{-1}\right), V$ is the volume of the accumulation vessel $\left(\mathrm{m}^{3}\right), m$ is the mass of the sample $(\mathrm{kg})$, and $C_{R n}^{0}$ $\left(\mathrm{Bq} \mathrm{m}^{-3}\right)$ is the ${ }^{222} \mathrm{Rn}$ activity concentration in the accumulation vessel at the start of an accumulation time $(t=0)$.

\section{RESULTS AND DISCUSSION}

\subsection{Radioactivity concentration in zircon materials and ceramic tiles}

Table 3 shows the average values and ranges for activity concentrations of naturally occurring radionuclides ${ }^{226} \mathrm{Ra},{ }^{232} \mathrm{Th}$ and ${ }^{40} \mathrm{~K}$. The activity concentrations in zircon materials ranged from 1,660 to $3,600 \mathrm{~Bq} \mathrm{~kg}^{-1}$ for ${ }^{226} \mathrm{Ra}$, from 270 to $500 \mathrm{~Bq} \mathrm{~kg}^{-1}$ for ${ }^{232} \mathrm{Th}$ and from 13 to $40 \mathrm{~Bq} \mathrm{~kg}^{-1}$ for ${ }^{40} \mathrm{~K}$, and these values are significantly higher than the values of ${ }^{238} \mathrm{U}\left(35 \mathrm{~Bq} \mathrm{~kg}^{-1}\right)$ and ${ }^{232} \mathrm{Th}\left(30 \mathrm{~Bq} \mathrm{~kg}^{-} 1\right)$ found in the Earth's crust [4].

On the contrary, ceramic tiles show lower activity concentrations, but still little above the average Earth's crust values.

Table 3. Activity concentrations of naturally-occurring radionuclides in zircon materials and ceramic tiles.

\begin{tabular}{|l|c|c|c|c|c|}
\hline \multirow{2}{*}{ Material } & \multirow{2}{*}{$\mathbf{n}$ samples } & \multicolumn{4}{|c|}{ Radioactivity concentrations (Bq $\mathbf{~ g g}^{-1}$ ) } \\
\cline { 3 - 6 } & \multirow{2}{*}{ Zircon materials } & $\mathbf{n ~ s a m p l e s}$ & ${ }^{\mathbf{2 2 6}} \mathbf{R a}$ & ${ }^{\mathbf{2 3 2}} \mathbf{T h}$ & ${ }^{\mathbf{4 0}} \mathbf{K}$ \\
\hline \multirow{3}{*}{ Ceramic tiles } & & Mean & $2640 \pm 650$ & $1100 \pm 160$ & $90 \pm 15$ \\
\cline { 3 - 6 } & \multirow{2}{*}{12} & Range & $1660-3600$ & $270-500$ & $13-40$ \\
\cline { 3 - 6 } & & Mean & $90 \pm 60$ & $50 \pm 10$ & $600 \pm 90$ \\
\cline { 3 - 6 } & & Range & $30-200$ & $40-80$ & $370-660$ \\
\hline
\end{tabular}

\subsection{Rate of radon exhalation from zircon materials and ceramic tiles}

The radon exhalation rates for the zircon flours and sands ranged from 0.17 to 1.9 , and from 0.090 to 0.20 , with average values of $0.6 \pm 0.3$ and $0.15 \pm 0.04 \mathrm{~Bq} \mathrm{~kg}^{-1} \mathrm{~h}^{-1}$, respectively (Figure 2). The radon

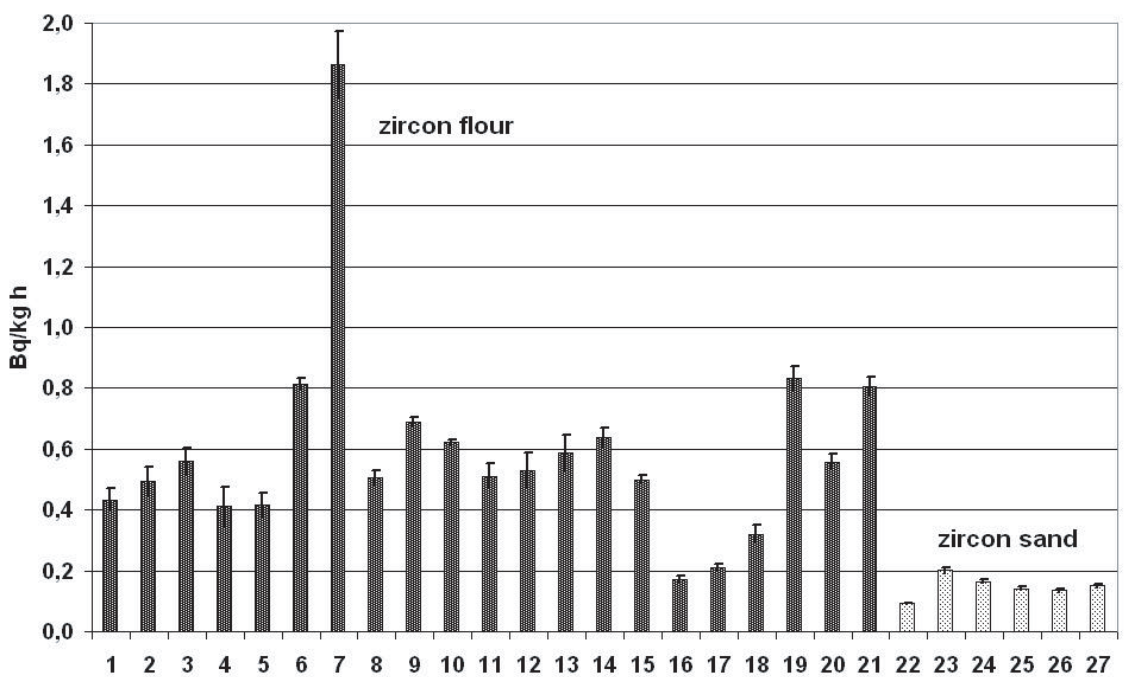

Figure 2. Radon exhalation rate from zircon materials (black bars: zircon flours; grey bars: zircon sands). 
exhalation rate for zircon sands was lower than that of zircon flours, and this result is consistent with the hypothesis that the finer the grain size, the larger the exposed surface area per unit mass, and the higher the ${ }^{222} \mathrm{Rn}$ exhalation rate is.

The radon emanation coefficient (2), defined as the fraction of radon atoms released into the material pore space from a radium bearing grain, for this type of materials is very low compared to that of other uranium-containing materials, because the escape of radon is inhibited by the fact that ${ }^{226} \mathrm{Ra}$, like its parent radionuclide ${ }^{238} \mathrm{U}$, is bound within the crystal lattice (Table 4).

$$
\eta=\frac{E}{C_{R a} \lambda_{R n}}
$$

where $E$ is the measured radon specific exhalation rate of the sample; $C_{R a}$ is the ${ }^{226} \mathrm{Ra}$ activity concentration and $\lambda_{R n}$ is the decay constant for ${ }^{222} \mathrm{Rn}$.

Table 4. Radon release data for zircon.

\begin{tabular}{|c|c|}
\hline & Radon emanation coefficient \\
\hline $\begin{array}{c}\text { Zircon flours (21 samples) } \\
\text { This study }\end{array}$ & $0.019-0.145$ \\
Average value $(0.034 \pm 0.002)$
\end{tabular}

The results presented in Table 5 illustrate that the ${ }^{222} \mathrm{Rn}$ exhalation rates for most of the porcelain stoneware tiles are near or below the minimum detectable limit (LLD) of $0.0004 \mathrm{~Bq} \cdot \mathrm{kg}^{-1} \cdot \mathrm{h}^{-1}$. The reason for that could be found in the production process (figure 3 ) and the characteristics of porcelain stoneware tiles. This type of tiles consists of a spray dried body of selected clays, quartz and feldspar, which is shaped by dry pressing and fired at temperatures of up to $1250{ }^{\circ} \mathrm{C}$. It is a uniform, monolithic product (although a glaze may be applied for decorative purposes) that has high water resistance, low porosity $(<0.5 \%)$, high mechanical strength and high stain resistance. The product consists of a glassy matrix of a feldspathic nature containing disperse crystalline phases such as quartz and mullite, therefore, it is highly probable that radon produced through the decay of radium after the vitrification process remains locked up in the glass-like matrix.

Table 5. Radon exhalation from ceramic tiles.

\begin{tabular}{|l|c|c|c|c|c|}
\hline Code & $\begin{array}{c}\text { Specific } \\
\text { exhalation rate } \\
\left(\mathbf{B q} \cdot \mathbf{~ k g}^{-1} \mathbf{h}^{-1}\right)\end{array}$ & $\begin{array}{c}\text { Radon emanation } \\
\text { coefficient } \mathbf{( \% )}\end{array}$ & Code & $\begin{array}{c}\text { Specific } \\
\text { exhalation rate } \\
\left(\mathbf{B q} \cdot \mathbf{k g}^{-1} \mathbf{h}^{-1}\right)\end{array}$ & $\begin{array}{c}\text { Radon emanation } \\
\text { coefficient }(\mathbf{\%})\end{array}$ \\
\hline $\mathbf{0 1}$ & $<$ to 0.0004 & - & $\mathbf{0 7}$ & $<$ to 0.0004 & - \\
\hline $\mathbf{0 2}$ & $0.0016 \pm 0.0008$ & 0.2 & $\mathbf{0 8}$ & $0.0010 \pm 0.0001$ & 0.4 \\
\hline $\mathbf{0 3}$ & $<$ to 0.0004 & - & $\mathbf{0 9}$ & $<$ to 0.0004 & - \\
\hline $\mathbf{0 4}$ & $<$ to 0.0004 & - & $\mathbf{1 0}$ & $<$ to 0.0004 & - \\
\hline $\mathbf{0 5}$ & $0.0016 \pm 0.0004$ & 0.2 & $\mathbf{1 1}$ & $0.0017 \pm 0.0004$ & 0.5 \\
\hline $\mathbf{0 6}$ & $<$ to 0.0004 & - & $\mathbf{1 2}$ & $<$ to 0.0004 & - \\
\hline
\end{tabular}




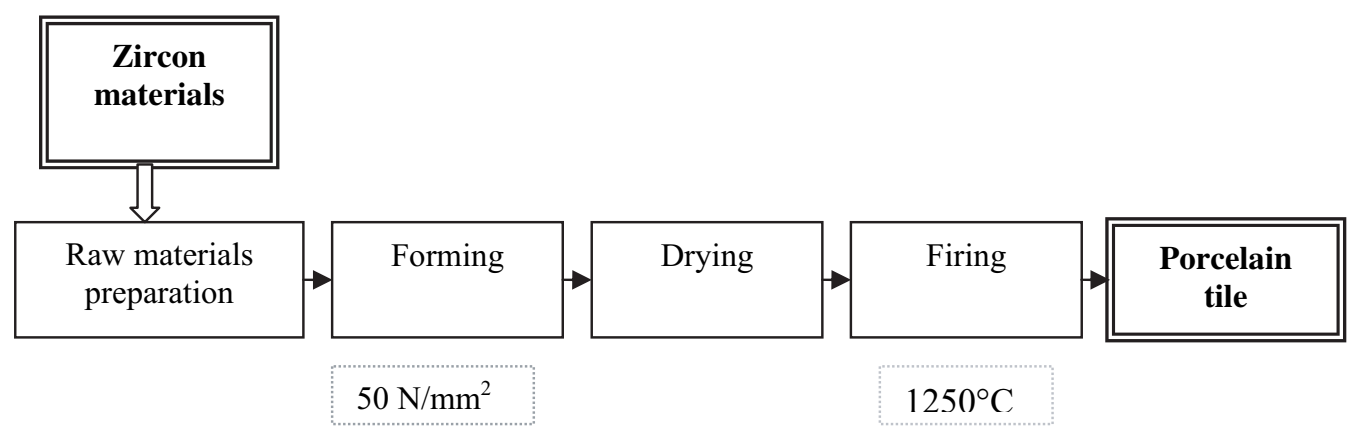

Figure 3. Porcelain tiles production process.

\section{CONCLUSIONS}

The geological processes that formed zircon and baddeleyite led to the incorporation of radionuclides of natural origin (i.e. those of the uranium and thorium decay series) into the crystal structure. The presence of these radionuclides creates a possible need to control exposures of workers and members of the public.

The activity concentrations of ${ }^{238} \mathrm{U}$ and ${ }^{232} \mathrm{Th}$ series radionuclides in Italian zircon sands and flours fall mostly in the ranges $1660-3600 \mathrm{~Bq} / \mathrm{kg}$ and $270-500 \mathrm{~Bq} / \mathrm{kg}$, respectively.

The activity concentrations of ${ }^{238} \mathrm{U}$ and ${ }^{232} \mathrm{Th}$ series radionuclides in the porcelain stoneware tiles fall mostly in the ranges $90-200 \mathrm{~Bq} / \mathrm{kg}$ and $40-80 \mathrm{~Bq} / \mathrm{kg}$, respectively.

The exposure pathways to workers and members of the public that are most likely to require consideration in the zircon and zirconia industries are those involving external exposure to gamma radiation emitted from bulk quantities of zirconium-containing material, and internal exposure via the inhalation of radionuclides in zirconium-containing dust. Internal exposure via the inhalation of radon emitted from zirconium containing material and via the ingestion of such material may also need to be considered.

This study shows that the measured ${ }^{222} \mathrm{Rn}$ exhalation rates from the porcelain stoneware tiles were at or below the minimum detectable exhalation rate; on the contrary, zircon sands and flours reported ${ }^{222} \mathrm{Rn}$ exhalation rate two order of magnitude higher. The most likely explanation for this observation is that the glassy matrix of the porcelain stoneware tile is impervious to diffusion of ${ }^{222} \mathrm{Rn}$ gas after it is released from the zircon grains.

Although high level of internal radiation exposure are potentially associated with zircon materials, low radon emanation coefficients are found in porcelain tiles. To sum up, the internal radiation exposure could be considered negligible, and the gamma radiation constitutes the major contribution to the indoor dose from ceramic tiles.

\section{Acknowledgments}

This work could not have been carried out without the collaboration with of the Health Physics Service of Ravenna Hospital and the skilful technical assistance of M. Carnevali and C. Orlandi. The authors wish to express their deep appreciation to the Institute of Advanced Studies for awarding a scholarship for Young Researchers to Dr. M. Jeyapandian to conduct a semestral activity of research at the Interdepartmental Centre for Environmental Science Research of Bologna University. The authors also are grateful to Prof. L. Bruzzi for his helpful suggestions and advice. Finally, the authors would like to thank Dr. A. Albertazzi, Dr. G. Bonvicini and E. Rastelli of Ceramic Centre of Bologna for the kind assistance in supplying and preparing the samples. 


\section{References}

[1] IAEA Radiation protection and NORM residue management in the zircon and zirconia industries (2007).

[2] P. Kotrappa and L.R. Stieff, Radiat. Prot. Dosim. 55, 211 (1994).

[3] R. Collé, P. Kotrappa and J.M.R. Hutchinson, Res. Natl. Inst. Stand. Technol. 100, 629 (1995).

[4] UNSCEAR Sources and Effects of Ionizing Radiation (2000).

[5] P. Tuccimei, M. Moroni and D. Norcia, Appl. Radiat. Isotopes 64, 254 (2006).

[6] D.E Bernhardt in Memorandum to Thomas Hill, Task Force on TENORM Rules (Part N), Conference of Radiation Program Control Directors (CRCPD), Frankfort, 2000.

[7] J.H. Selby in Proc. $3^{\text {rd }}$ Int. Symp. Brussels, 2001, edited by Federal Agency for Nuclear Control.

[8] W.W. Nazaroff, B.A. Moed and R.G. Sextro, Radon and its Decay Products in Indoor Air, 57 New York (1988). 
